\title{
Analysis of Guidance and Counselling Services at Higher Education in Punjab,
}

\section{Pakistan}

\author{
* Mubashira Khalid, Assistant Professor \\ ** Tanveer Iqbal, Assistant Professor \\ *** Shazia Bibi, Lecturer
}

\begin{abstract}
In this century, the world is undergoing many changes in social and economic arena. All these changes are opening door to many opportunities for young people who wish to enter in professional life; and choosing a career is becoming a complex task. The students when entering and leaving the higher education are required to explore their prospects at national and global level (Gybers, 2001). Thus, higher education institutions are required to offer the information through guidance and counselling services. In Pakistan, there are limited guidance and counselling services in higher education. Therefore, the current study was designed to investigate the need of career development at higher education level. The objectives of the study were to; (1) find out the existing practices of guidance and career development; (2) investigate the need of educational, social, emotional and psychological dimension of guidance and counselling, (3) explore the students' need of guidance and counselling regarding career selection. All the public sector universities of Punjab were the population of the study. Cluster sampling technique was used at first stage for the selection of universities, and stratifies sampling technique were used for the selection of sample. Four universities were selected as cluster and 1003 students (579 female and 424 male) were selected from twenty departments from all four universities. A self-developed instrument was the tool to collect data; the instrument was based on five Likert scale. The tool was pilot-tested in a local university for the reliability of instrument. Cronbach Alpha test was applied and the value of this test was 0.853; the value showed the reliability of instrument. For the purpose of derivation of results, the data were analyzed through percentage and ANOVA by using SPSS. The results of the study showed that although there is some Guidance and Counselling practices exist in some of universities, but working at limited scale is not enough for the population of students enrolled in the universities. But, there is need of guidance and counselling educational, social, emotional, and psychological and career selection in all universities. Need of Guidance \& counselling for career selection had been profoundly felt. The comparison among universities Bahauddin Zakariya University Multan was found to be in difference with the rest of three universities on prevailing practices of Guidance \& counselling. In Bahauddin Zakariya University Multan, there was more need of all educational, social, emotional, psychological and career selection of guidance and counselling.
\end{abstract}

Keywords: Guidance; Counselling; Higher Education; Educational; Psychological; Social; Emotional Introduction

Pakistan is undergoing substantial changes in economic, social and occupational structures in $21^{\text {st }}$ century like the rest of the world. Occupational and industrial specialization is continuously increasing. All these changes are creating challenges for students as they are going to enter in the professional life. They are required to know their prospects not only at national level but also to explore the opportunities available to them at global level (Gybers, 2001). Thus, higher education institutions are required to offer the information to their graduates regarding future work and prospects of further education through guidance and counselling services. The main aim of guidance and counselling is to facilitate learners in self-evaluation and analysis of alternatives so that every student can get full advantage of his/her experiences and education and reach to full potential.

Guidance and counselling play a vital role at higher education level, and they are required to be provided at Higher education level. Students face many problems at higher level and for the

\footnotetext{
* Institute of Education and Research, University of the Punjab, Lahore Email: mubushirakhalid@ yahoo.com

** Department of Education, University of Lahore Email: tanveer 242@ @otmail.com

*** Department of Education, University of Lahore Email: shazia121323@yahoo.com
} 
solution of their problems; the universities should provide the helping services to students. When Students join higher education from different places, they belong to different area, have different socio-economic backgrounds, and different language and culture. They face many problems in subject selection, adjustments in classroom, university environment and in hostel residence away from home. For this purpose, the students need guidance and counselling during this transition period of higher education (Arthur, 2014).

The main purpose of the study is to assess the need of guidance and counselling at higher education level. The focus of the study was to investigate the need of guidance and counselling regarding educational, social, emotional, and psychological problems and career selection choices at higher level. At the higher level, the students face many problems in education; understanding the lecturer and different topics. They also face social, emotional and psychological problems, like dealing with some peoples, adjustment in hostel life, making some friends and as well. Furthermore, they face career selection problems and choosing subjects to take admission in various departments (Arthur, 2014)

For the purpose of the help, the main focus is to understand the concept of guidance and counselling. Need of Guidance and counselling is very important at higher level. Guidance means to guide, provide help, and provide the direction, to accomplish, to adjust, to steer, to show, to control, to point for their convenient. Merriam Webster's Dictionary (2007)

Guidance means to provide help to a person to take decisions regarding their problems, for choosing a discipline and what he wants to do in his life. Guidance means to give the direction to the students and support them for solving problems which they face in their daily life. Guidance means to help the students to overcome their worries, guide them, support them and enable them to solve their problems. The focus of guidance is not just the solution of the problems; its main focus to provide the direction to the students so that they can solve their problem by themselves. Guidance is not just providing help to groups or to individuals, but it is designed for whole society and community (Merriam Webster's Collegiate Dictionary 2007).

Counselling means to provide help to the individual regarding social and emotional problems. In Counselling, a client and counsellor meet to overcome difficulties that create a feeling of stress and pain for client. They both discuss the feeling of anxiety and depression that are painful for client. Counselling is the act of helping the client, to help him to overcome his feelings of anxiety and depression. Counselling is the relationship of trust and confidence. Counselling is the process in which a counsellor talks face to face with another person to help him in solving his personal problem, or help him to improve person's feelings, manners, or moral conduct.

Educational Guidance means to provide guidance in field of education. When students face educational problems like, choosing the subject, understanding the different concepts and help in reading materials and comprehension of lectures, this type of guidance is provided to them. Social Guidance is also the process of helping the students in social adjustment like, in classroom and relationship with class fellows and other peers.

Moral Guidance means the guidance provided to the students for their moral support. At the stage of higher level, students come from different areas and different backgrounds, they face behavior problems, they feel loneliness in hostels, they want moral support, and they miss their home, family, and friends. So for this purpose there is also a need of moral guidance for students (Lunenburg, 2010).

Psychological Guidance is also the process of guidance, students face many psychological issues like loneliness, fear of lecture, fear of class and fear of examination. For this purpose, the psychological guidance is provided to the students. Guidance and counselling is required at all stages of life. Guidance related to the career selection is also provided to the students. When students enter in universities, they want freedom. They do not like any restriction in their matters. For this purpose, all types of guidance provided at this stage.

The current study regarding Guidance and Counselling may be helpful for students, parents and teachers. It will help universities to look into their Guidance and Counselling services to improve and make these more accessible for students. It will help students to select correct occupation and make correct choices about their upcoming future. In this way, students will adjust in classrooms as well as in social environment. The purpose of this study was to explore the need of guidance and Counselling in higher education institutions in Punjab. 


\section{Objectives of the Study}

The objectives of the study were as the following.

1- $\quad$ To find current practices of guidance and counselling at higher level

2- To explore the need of educational, social, emotional and psychological dimensions of guidance and counselling

3- $\quad$ To explore the students' need regarding career selection

\section{Research Hypothesis}

$\mathbf{H}_{01}$ There is no significant difference among selected universities of Punjab regarding prevailing practices.

$\mathbf{H}_{0}$ 2. There is no significant difference among selected universities of Punjab regarding educational dimension.

$\mathbf{H}_{\mathbf{0}}$ 3. There is no significant difference among selected universities of Punjab regarding social dimension.

$\mathbf{H}_{\mathbf{0}}$ 4. There is no significant difference among selected universities of Punjab regarding emotional dimension.

$\mathbf{H}_{\mathbf{0}}$ 5. There is no significant difference among selected universities of Punjab regarding psychological dimension.

$\mathbf{H}_{0}$ 6. There is no significant difference among selected universities of Punjab regarding career selection of subjects.

\section{Review of Related Literature}

Guidance \& counselling are two popular synonymous terms generally used while making educational as well as career choices. Merriam Webster's Collegiate Dictionary $(2007: 555,284)$, defines guidance as an "advice on vocational or educational problems given to students"; whereas, counselling is a "professional guidance of the individual by utilizing psychological methods especially in collecting case history data, using various techniques of the personal interview, and testing interests and aptitudes". Nevertheless, there is a subtle difference in deeper connotation of the two terms i.e. former is an advice and the latter is the consultation.

According to Joseph (2002) "Guidance involve personal help given by someone, it is designed to assist a person in deciding where he/she wants to go, what he/she wants to do, or how he/she can best accomplish his/her purposes, it assists in solving problem that arises in his/her life"'(Rashid \& Joseph, 2002).It is the process of helping individuals discover and develop their educational, vocational and psychological potentialities" (Encycholopedia Britannica, 2015).

"Counselling is an accepting, trusting and safe relationship in which clients learn to discuss openly what worries upset them, to define precise behaviour goals, to acquire essential social skills, and to develop the courage and self-confidence to implement desired new behaviours"(Yousaf \& Yousaf, 2004)."The process that occurs when a client and counsellor set aside time in order to explore difficulties which may include the stressful or emotional feelings of the Client?" (Gysbers, \& Henderson, 2014).

Primary emphasis of guidance and counselling was on guidance activities. Now-a-days guidance \& counselling services and programs are in practice. Guidance \& counselling services are solving higher education level problems (Dogar, Azeem, Majoka, \& Mehmood, 2011). Guidance \& counselling practices help the peoples to overcome their difficulties, worries and problems (Dogan, 2000). People can get help from community through collaboration and co-operation (Bernes, Bardick, $\&$ Orr, 2007). Individuals take help through formal and informal channels (Bernes et al., 2007). The main purpose of the guidance and counselling is to help the people and overcome their problems and difficulties.

The higher education level students come from differing backgrounds. Students face new curriculum, new competitive environment, and difficulties in adjustment. They do not know about the challenging environment of the university. For this purpose, they need guidance and counselling practices at higher education level (Goh \& Lee, 2003).

There are two stages when students need guidance \& counselling services. Firstly, when they need to take admission in colleges or university for higher studies. Secondly, when they need to take decision about their career choices. 


\section{Research Methodology}

The study was quantitative in nature. This was descriptive type of study. The researcher used survey research design to collect the data.

\section{Population and Sampling}

All the public universities of the Punjab were selected as the population for the current study. The researcher randomly selected 4 universities of the Punjab, University of the Punjab Lahore, University of Gujarat, University of Sargodha and Baha Uddin Zakariya University Multan. Through simple random sampling technique 1003 (about 250 from each university) students were selected as a sample for the present study.

\section{Research Instrument}

A self-developed questionnaire was used for this study. Questionnaire was developed with a keen focus on all the extents, perspectives and objectives of the present study.

\section{Analysis and interpretation of Data \\ Parentage of respondents for all dimensions \\ Table 01 Percentage of the respondents}

\section{Dimensions}

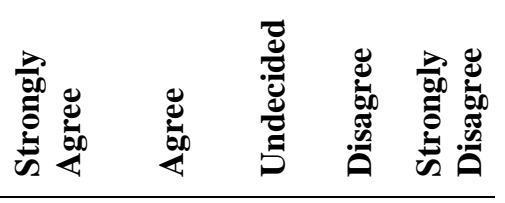

\section{A. Prevailing Practices of Guidance \& Counselling}

1. Guidance \& counselling practices exist in universities

2. Guidance \& counselling practices work an informal way in universities

3. Guidance \& counselling practices manage the student's activities

4. Guidance \& counselling practices provide the quality services

5. Guidance $\&$ counselling practices play an active role in university

6. Existence of Guidance \& counselling practices is necessary in university

7. Informal Guidance \& counselling practices fulfil the needs of the students

B. Educational dimension of Guidance \& Counselling

8. Students need guidance and counselling for show improvement in their examination

9. Students required guidance and counselling for solve their learning problems

10. Students need guidance \& counselling to understand their lecture

11. Students need guidance and counselling for show deeply interest in their studies

C. Social dimension of Guidance $\&$ Counselling

12. Students need guidance and counselling for adjustment in class room environment

13. Students need guidance \& counselling for understanding of social values/norms

14. Students need guidance \& counselling for show good character in their society

15. Students need guidance and counselling for the welfare of the society

D. Emotional dimension of Guidance \& Counselling

16. Students need guidance \& counselling for express their feelings and emotions in proper way

17. Students need guidance \& counselling for show good attitudes to others

18. Students need proper guidance \& counselling for control their-self

19. Students need guidance and counselling to learn the manners in their life

E. Psychological dimension of Guidance \& Counselling

\begin{tabular}{|c|c|c|c|c|}
\hline 42.5 & 48.6 & 1.0 & 7.2 & 0.8 \\
\hline 29.0 & 58.0 & 2.9 & 9.4 & 0.7 \\
\hline 39.6 & 53.5 & 2.2 & 4.4 & 0.3 \\
\hline 36.8 & 56.9 & 1.8 & 4.2 & 0.3 \\
\hline 47.9 & 47.3 & 1.9 & 2.8 & 0.2 \\
\hline 58.4 & 39.1 & 1.2 & 0.7 & 0.6 \\
\hline 36.7 & 51.2 & 3.1 & 7.6 & 1.4 \\
\hline 52.8 & 44.0 & 1.6 & 1.1 & 0.5 \\
\hline 47.1 & 49.8 & 1.0 & 1.8 & 0.4 \\
\hline 48.7 & 47.6 & 1.1 & 2.5 & 0.2 \\
\hline 50.5 & 45.4 & 1.2 & 2.4 & 0.5 \\
\hline 46.9 & 48.8 & 1.8 & 2.0 & 0.6 \\
\hline 39.4 & 55.7 & 1.9 & 2.8 & 0.2 \\
\hline 47.8 & 47.8 & 1.1 & 2.7 & 0.7 \\
\hline 43.5 & 50.4 & 2.1 & 3.4 & 0.6 \\
\hline 43.4 & 51.8 & 1.6 & 2.6 & 0.6 \\
\hline 42.5 & 52.9 & 1.4 & 2.2 & 1.0 \\
\hline 42.4 & 52.3 & 1.6 & 3.0 & 0.7 \\
\hline 43.9 & 51.4 & 2.0 & 2.2 & 0.5 \\
\hline
\end{tabular}




\begin{tabular}{|c|c|c|c|c|c|}
\hline 20. Students need guidance and counselling to get self-recognition & 42.1 & 53.5 & 1.9 & 2.0 & 0.5 \\
\hline $\begin{array}{l}\text { 21. Students need guidance and counselling to aware weak point of } \\
\text { their personality }\end{array}$ & 45.4 & 50.0 & 1.2 & 3.0 & 0.5 \\
\hline $\begin{array}{l}\text { 22. Students need guidance \& counselling to safe different mental } \\
\text { disorders }\end{array}$ & 36.1 & 56.6 & 2.9 & 3.8 & 0.6 \\
\hline F. Career Selection & & & & & \\
\hline $\begin{array}{l}\text { 23. Students need proper guidance \& counselling for awareness of } \\
\text { different areas of courses/subject }\end{array}$ & 50.8 & 46.8 & 0.7 & 1.4 & 0.3 \\
\hline $\begin{array}{l}\text { 24. Students need guidance \& counselling to get the knowledge/skills } \\
\text { of different professional courses }\end{array}$ & 42.4 & 54.2 & 0.7 & 2.6 & 0.1 \\
\hline $\begin{array}{l}\text { 25. Students need guidance and counselling for awareness of future } \\
\text { profession }\end{array}$ & 53.3 & 43.1 & 1.2 & 2.0 & 0.4 \\
\hline $\begin{array}{l}\text { 26. Students need guidance \& counselling to understand the different } \\
\text { technical courses }\end{array}$ & 40.8 & 55.2 & 1.1 & 2.4 & 0.5 \\
\hline
\end{tabular}

According to the Table 1, It was observed that more than 87 percent of the respondents reacted positively i.e. either agreed or strongly agreed. This detail for the six dimensions is given here. For "Prevailing Practices of Guidance \& counselling", it was 87 to 97.5; for "Educational dimension", 95.9 to 96.9; for "Social dimension", 93.9 to 95.7; for "Emotional dimension", 94.7 to 95.4; for "Psychological dimension", 92.7 to 95.6 and for "Career Selection", 96 to 97.6.

\section{Comparison of perception of Students from the universities}

F-test was applied in order compare the universities for each dimension. Further analysis was done to localize the difference among universities in one-to-one relationship.

Table 02. University wise comparison of students' perception

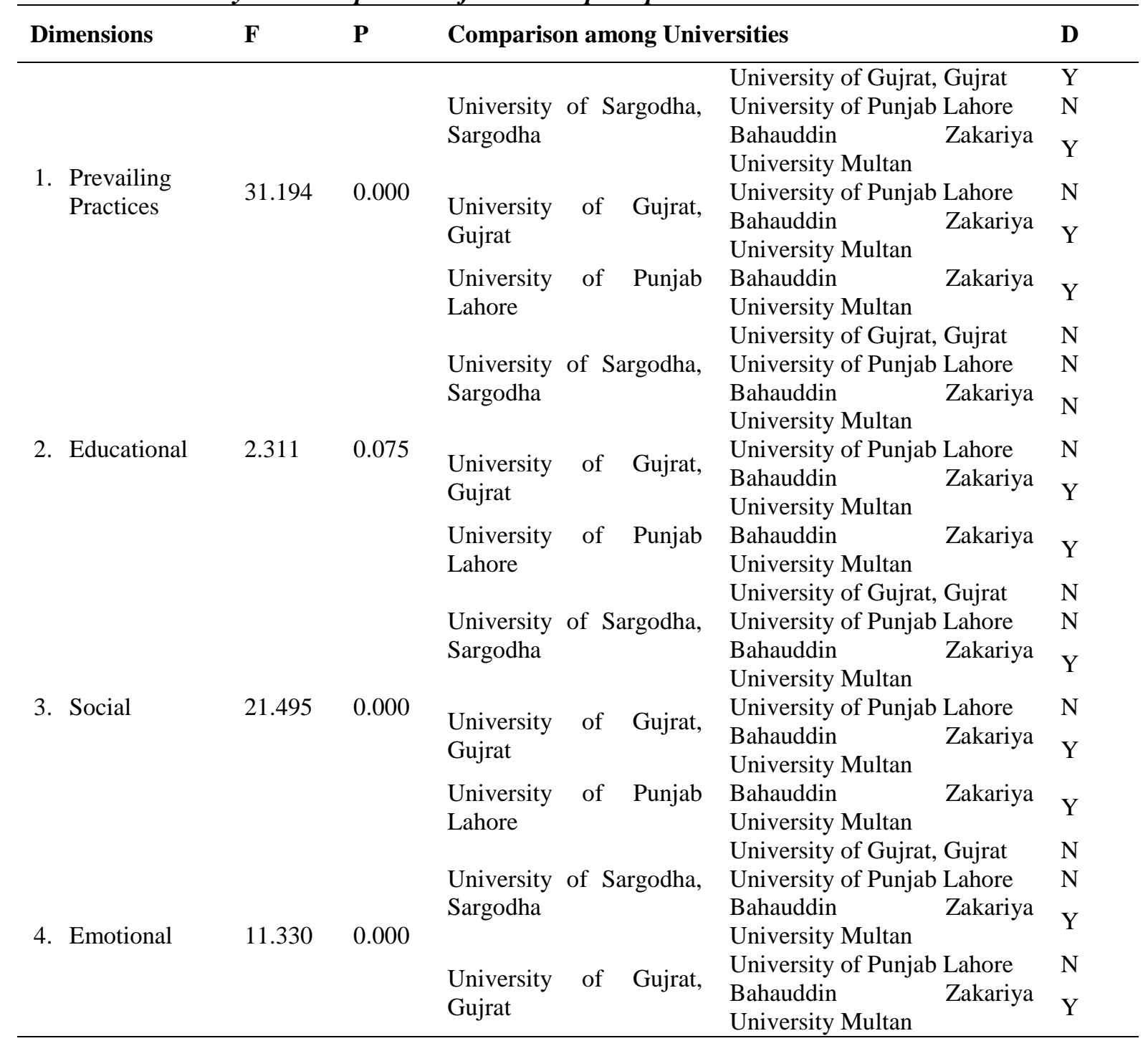




\begin{tabular}{|c|c|c|c|c|c|c|c|}
\hline & & & $\begin{array}{l}\text { University } \\
\text { Lahore }\end{array}$ & of Punjab & $\begin{array}{l}\text { Bahauddin } \\
\text { University Multan }\end{array}$ & Zakariya & $\mathrm{Y}$ \\
\hline \multirow{6}{*}{ 5. Psychological } & \multirow{6}{*}{17.160} & \multirow{7}{*}{0.000} & \multirow{3}{*}{\multicolumn{2}{|c|}{$\begin{array}{l}\text { University of Sargodha, } \\
\text { Sargodha }\end{array}$}} & \multirow{2}{*}{\multicolumn{2}{|c|}{$\begin{array}{l}\text { University of Gujrat, Gujrat } \\
\text { University of Punjab Lahore }\end{array}$}} & $\mathrm{N}$ \\
\hline & & & & & & & $\mathrm{N}$ \\
\hline & & & & & $\begin{array}{l}\text { Bahauddin } \\
\text { University Multan }\end{array}$ & Zakariya & $\mathrm{Y}$ \\
\hline & & & & & University of Punjab & Lahore & $\mathrm{N}$ \\
\hline & & & Gujrat & Gujrat, & $\begin{array}{l}\text { Bahauddin } \\
\text { University Multan }\end{array}$ & Zakariya & $\mathrm{Y}$ \\
\hline & & & $\begin{array}{l}\text { University } \\
\text { Lahore }\end{array}$ & of Punjab & $\begin{array}{l}\text { Bahauddin } \\
\text { University Multan }\end{array}$ & Zakariya & $\mathrm{Y}$ \\
\hline \multirow{6}{*}{$\begin{array}{l}\text { 6. Career } \\
\text { selection }\end{array}$} & \multirow{6}{*}{10.460} & & & & University of Gujrat, & Gujrat & $\mathrm{N}$ \\
\hline & & \multirow{5}{*}{0.000} & University & \multirow{2}{*}{ of Sargodha, } & University of Punjab & Lahore & $\mathrm{N}$ \\
\hline & & & Sargodha & & $\begin{array}{l}\text { Bahauddin } \\
\text { University Multan }\end{array}$ & & $\mathrm{Y}$ \\
\hline & & & & Guirat & University of Punjab & Lahore & $\mathrm{N}$ \\
\hline & & & Gujrat & uajtat, & $\begin{array}{l}\text { Bahauddin } \\
\text { University Multan }\end{array}$ & Zakariya & $\mathrm{Y}$ \\
\hline & & & $\begin{array}{l}\text { University } \\
\text { Lahore }\end{array}$ & of Punjab & $\begin{array}{l}\text { Bahauddin } \\
\text { University Multan }\end{array}$ & Zakariya & $\mathrm{Y}$ \\
\hline
\end{tabular}

Level of significance $(\alpha=0.05)$

$\mathbf{H}_{\mathbf{0 1}}$ There is no significant difference among selected universities of Punjab regarding prevailing practices.

Table above determined on the basis of $\mathrm{p}$ value that there is significant difference among selected universities of Punjab for the first dimension of Guidance \& counselling i.e. prevailing practices. Hence, it is concluded that the null hypothesis "there is no significant difference among selected universities of Punjab about prevailing practices of guidance and counselling" was rejected. According to the post hoc analysis, University of Sargodha did not vary with University of the Punjab but varied with University of Gujrat and Bahauddin Zakariya University Multan. University of Gujrat too did not be differ from University of the Punjab but fluctuated with Bahauddin Zakariya University Multan. University of the Punjab differed from Bahauddin Zakariya University.

$\mathbf{H}_{\mathbf{0}}$ 2. There is no significant difference among selected universities of Punjab regarding educational dimension.

The second dimension in the above table revealed no significant difference among universities of Punjab. Hence, it is determined that the null hypothesis "there is no significant difference among selected universities of Punjab about educational guidance" was failed to be rejected. The post hoc analysis need not to be inferred at all.

$\mathbf{H}_{0}$ 3. There is no significant difference among selected universities of Punjab regarding social dimension.

Social dimension in above table show noticeable significant difference among universities of Punjab. Hence, the null hypothesis "there is no significant difference among selected universities of Punjab about social guidance" was rejected. Social dimension in above table manifests significant difference among universities of Punjab. Hence the null hypothesis "there is no significant difference among selected universities of Punjab about social guidance" was rejected. Post hoc analysis exposed that it was only Bahauddin Zakariya University which fluctuated with the rest of all three universities. $\mathbf{H}_{\mathbf{0}}$ 4. There is no significant difference among selected universities of Punjab regarding emotional dimension.

It was pragmatic that there is significant difference among universities of Punjab about emotional dimension of Guidance and counselling. The null hypothesis "there is no significant difference among selected universities of Punjab about emotional dimension of Guidance \& counselling" was precluded. According to the post hoc analysis, there is difference between Bahauddin Zakariya University and all the other three universities.

$\mathbf{H}_{\mathbf{0}}$ 5. There is no significant difference among selected universities of Punjab regarding psychological dimension.

Above table demonstrated significant difference among universities of Punjab about psychological dimension of Guidance and counselling. Consequently, the null hypothesis "there is no 
significant difference among selected universities of Punjab about psychological dimension of Guidance and counselling" was rejected. Post hoc analysis wide-open Baha Uddin Zakariya University as the odd-man-out, while the rest of three universities did not show any modification in one-to-one relation concerning psychological dimension of Guidance and counselling.

$\mathbf{H}_{0}$ 6. There is no significant difference among selected universities of Punjab regarding career selection of subjects.

For the last dimension of guidance \& counselling i.e. Career Selection significant difference was obvious among universities of Punjab. Subsequently, the null hypothesis "there is no significant difference among selected universities of Punjab about Guidance \& counselling for Career Selection of subjects" was rejected. As articulated through the post hoc analysis, there is difference between Bahauddin Zakariya University and all three universities in the sample.

\section{Summary}

The present study was conducted to investigate the need of the guidance and counselling at the higher education level. The leading objectives formulated of the study were: to find out the prevailing practices of Guidance and counselling in universities; to analyze the need of Guidance and counselling related to the educational, social, emotional and psychological dimensions; to explore the students need for their career selection.

Population of the present study was all public sector universities of Punjab. Universities in the sample were the University of Sargodha, University of Gujarat, University of the Punjab Lahore, and Bahauddin Zakariya University Multan, selected. The study focused on MA/MSC level students in Punjab. Sample of the study was 1003 students. The researcher used quantitative research design. The present study was descriptive in nature. The researcher used survey method for collection of data. The instrument of the study was questionnaire.

Current status originates out that Guidance and counselling practices are prevalent in the universities. It was found that at the sampled universities, there was the need of educational, social, emotional and psychological Guidance and counselling. Need of Guidance and counselling for career selection had been overpoweringly felt. Approximately, all the students regardless of their age, gender and domiciliation expressed the opinion that there was the need of guidance and counselling in all dimension. Bahauddin Zakariya University Multan seemed to be different among four sampled universities in this study that it does not have any kind of guidance and counseling services.

\section{Findings}

Following were the findings of the study.

Overall 87-97.6 percent of the respondents expressed positively, 1.3-10.1 percent negatively and 0.73.1 percent preferred to be undecided on the scale. First dimension on the scale "Prevailing Practices of Guidance \& counselling" was confirmed by $87-97.5 \%$; the second "Educational dimension" by 95.9- 96.9\%; the third "Social dimension" by 93.9-95.7\%; the fourth "Emotional dimension" by 94.795.4\%; the fifth "Psychological dimension" by 92.7- 95.6\%; and the last "Career Selection" by 96$97.6 \%$.

Statistically significant differences were found among all four universities in the sample on the first dimension of Guidance and counselling. Bahauddin Zakariya University Multan was found to differ from the rest of three universities on prevailing practices of Guidance and counselling; whereas another remarkable finding was that the University of Sargodha differed from University of Gujarat on this first dimension of Guidance and counselling. No difference was found among all four universities upon educational dimension of Guidance and Counselling. For social dimension of Guidance and Counselling it was Bahauddin Zakariya University Multan which differed from the rest of three universities in the sample. Bahauddin Zakariya University Multan was also found to be reflecting its difference with the rest of three universities on emotional dimension of Guidance and Counselling. Bahauddin Zakariya University Multan was again found to be reflecting its difference with the rest of three universities on psychological dimension of Guidance and Counselling. For the last dimension of Guidance and counselling i.e. Career Selection, it was yet again Bahauddin Zakariya University Multan which differed from the rest of three universities in the sample.

\section{Discussion}

Prevalence of Guidance and counselling practices was confirmed by respondents on the Guidance \& counselling scale. The analyses emphasized upon the need of educational, social, emotional and psychological dimension of Guidance and counselling. Need of Guidance and counselling for career 
selection was also emphasized heavily. Nearly all the students regardless of their age, gender and domiciliation likewise endorsed the aforesaid inferences.

However, as the study explored that the universities in our sample have difference of prevailing practices of Guidance and counselling. As compared to other universities, the students from Bahauddin Zakariya University Multan were different in the prevailing practices of Guidance and counselling in their university. Likewise, the students from the University of Sargodha and the University of Gujarat were not of the same opinion on the prevailing practices of Guidance and counselling.

The students from Bahauddin Zakariya University Multan exclusively differed from other three universities in their belief upon the social, emotional, and psychological need of Guidance and counselling. Nevertheless, all the students equally believed in educational need of Guidance \& counselling. The need of Guidance and counselling for career selection was differently emphasized exclusively by the students of Bahauddin Zakariya University Multan as compared to their peers from other three universities.

\section{Conclusion}

The findings reveal that the majority of the respondents confirmed the predominance of practices of all six dimensions of guidance and counselling; and have faith in its educational, social, emotional and psychological roles to them along with the contributing influence towards their vocation selection. Almost all the learners regardless of their age, gender and domiciliation similarly expressed the same opinion about the above dimensions.

The universities in our sample have dissimilar prevailing practices of guidance and counselling. Associated to their complements from other three universities, the students from Bahauddin Zakariya University Multan were uncertain on the prevailing practices of guidance and counselling in their university. Similarly, the students from the University of Sargodha and the University of Gujrat did not have similar estimation on the prevailing practices of guidance and counselling. Exclusively, the students from Bahauddin Zakariya University Multan did not suppose upon the social, emotional, and psychological need of guidance and counselling, to the point their equivalents did consider. But they do rely on in educational assistances like the students from other universities in the sample. The students from all four universities in the sample consistently preferred the need of educational dimension of guidance and Counselling. Again, specifically the students from Bahauddin Zakariya University Multan revealed slighter confidence in the need of Guidance with counselling for career selection as associated to their complements from other three universities under study.

\section{Recommendation}

On the basis of existing study additional intensive emphasis upon operational prevailing practice of guidance and counselling may be endorsed at all the universities. The need of guidance and counselling in educational, social, emotional and psychological dimensions is suggested. Henceforward, the need of guidance and counselling for career selection is also acclaimed to be more emphasized.

* Similar study with larger data set may give more valid results to be comprehensive to national level.

* Longitudinal repetition of the same study may also be beneficial for long-lasting allegations in ambiance of higher education at regional and nationwide level.

* As this study was surrounded to public universities, enclosure of private sector may condense more inclusive picture of guidance and counselling facilities.

* Based of literature over the world, larger possibility and more magnitudes of guidance and counselling services may also be a thought-provoking research which may be undertaken in future.

\section{References}

Arthur, N. (2014). Social justice and career guidance in the age of talent International Journal Educational Vocational Guidance, 14(14), 47-60. doi: 10.1007/s10775-013-9255-x

Bernes, K. B., Bardick, A. D., \& Orr, D. T. (2007). Career guidance and counseling efficacy studis: An international research agenda. international Journal Educational Vocational Guidance, 7(7), 81-96. doi: 10.1007/s10775-007-9114-8 
Council for Accreditation of Counselling and Related Educational Programs. (2016). Why Become a Professional Counsellor. Retrieved from http://www.cacrep. Org/for-students/why-become-aprofessional-counselor/

Dogan, S. (2000). The Historical Development of Counseling In Turkey. International Journal For the Advancement of Counseling, 22(4), 57-67.

Dogar, A. Hussain, Azeem, M., Majoka, M. Iqbal, \& Mehmood, A. (2011). Need Assessment of Students Guidance and Counseling. British Journal of Arts and Social Sciences, 1(2).

Gybers, N. C. (2001). School guidance and counselling in the $21^{\text {st }}$ century: Remember the past into future. Professional School Counselling, 5(2), 96.Goh, M., \& Lee, J. Kyung. (2003). Career Counseling centre in Higher education. United states Korea, 4(1), 84-96.

Gysbers, N. C., \& Henderson, P. (2014). Developing and managing your school guidance and counselling program. John Wiley \& Sons.

Lunenburg, F. C. (2010). School Guidance and Counseling Services. 1(1), 1-9.

Merriam Webster's Collegiate Dictionary (2007). Encycholopedia Britannica.

Rashid, M., \& Joseph, M. (2002). Allied Material of Educational Guidance and Counseling (Vol. 1). Allama Iqbal Open University: Allama Iqbal Open University.

Society for Counselling Psychology. (2017). Counselling Psychology vs Clinical Psychology. Retrieved from http://www.div17.org/about-cp/counseling-vs-clinical-psychology/

The International Registry of Counsellor Education Programs (IRCEP). (2018). Definition of Counselling. Retrieved from http://www.ircep.org/ircep/template/ page.cfm? Id=151

Yousaf, M., \& Yousaf, S. (2004). Psychology (Vol. 1). Lahore: G.F 